\title{
A Russian Bank in the Khanate of Khiva of Novo-Urgench Branch of the Russo-Asiatic Commercial Bank
}

\author{
B. A. Alimdjanov, D. G. Yanchenko
}

For citation: Alimdjanov B. A., Yanchenko D. G. A Russian Bank in the Khanate of Khiva of NovoUrgench Branch of the Russo-Asiatic Commercial Bank. Vestnik of Saint Petersburg University. History, 2020, vol. 65, issue 3, pp. 790-813. https://doi.org/10.21638/11701/spbu02.2020.306

Cotton farming, being one of the leading branches of economic activity of Turkestan of the beginning of the $20^{\text {th }}$ century, attracted the attention of big investors of the Russian Empire. This article examines functioning of the Novo-Urgench branch of the Russo-Asian commercial bank (RACB) on the basis of the material from Russian State Historical Archive (RGIA): successful and unsuccessful operations, organizational structure, interaction with clients, and its influence on the regional market. The unique character of this branch of one of the largest Russian banks lay in that fact that it was the only lending and financial institution that expanded its operations throughout the entire oasis of Khiva, including territories that were under control of the Khan of Khiva. Both local political and economic elites and entrepreneurs from Central Russia were clients and partners of the Novo-Urgench branch of the bank. Wide-spread liaisons allowed the institution to promptly conquer and maintain, even under conditions of a crisis, its niche on the market of financial services in Central Asia. On the threshold of the World War I, the bank attempted to monopolize cotton farming, working with big clients and even stimulating development of the processing industry. Novo-Urgench branch of the Russo-Asian bank provided help to the local merchantry trying to increase export of raw cotton and to enter both Russia-wide and international markets. For the objective reasons of shortage of liquid assets, underdeveloped infrastructure of the region, swings in stock-exchange and problems with human resources, the Novo-Urgench branch of the Russo-Asiatic bank could not capture and control the Khivan market. During the war years, the

Bakhtiyor A. Alimdjanov - PhD in History, Postdoctoral Student, Al-Beruni Institute of Oriental Studies of Uzbekistan, 79, ul. M. Ulughbeka, Tashkent, 100179, Uzbekistan; Visiting Researcher, St. Petersburg State University, 7-9, Universitetskaya nab., St. Petersburg, 199034, Russian Federation; felix_1985@mail.ru

Бахтиёр Абдихакимович Алимджанов - канд. ист. наук, докторант, Институт Востоковедения им. Абу Райхана Беруни, Узбекистан, 100179, Ташкент, ул. М. Улугбека, 79; приглашенный исследователь, Санкт-Петербургский государственный университет, Российская Федерация, 199034, СанктПетербург, Университетская наб., 7-9; felix_1985@mail.ru

Denis G. Yanchenko - PhD in History, Associate Professor, St. Petersburg State University, 7-9, Universitetskaya nab., St. Petersburg, 199034, Russian Federation; d.yanchenko@spbu.ru

Денис Геннадьевич Янченко - канд. ист. наук, доц., Санкт-Петербургский государственный университет, Российская Федерация, 199034, Санкт-Петербург, Университетская наб., 7-9; d.yanchenko@spbu.ru

The study was supported by the research grant No.18-18-00142 "The Center and the regions: state economic policy on the outskirts of the Russian Empire (1894-1917)" of the Russian Science Foundation

Исследование выполнено за счет средств проекта РНФ № 18-18-00142 «Центр и регионы: экономическая политика правительства на окраинах Российской империи (1894-1917)».

(c) Санкт-Петербургский государственный университет, 2020 
Central Asian periphery was under the influence of the problems characteristic of not only the banking sector, but Russian economy as a whole.

Keywords: Russian-Asian Commercial Bank, Khanate of Khiva, Turkestan, cotton, alfalfa, Russian Empire.

\section{Российский банк в Хивинском ханстве Ново-Ургенчского отделения Русско-Азиатского коммерческого банка}

\section{Б. А. Алимджанов, Д. Г. Янченко}

Для цитирования: Alimdjanov B. A., Yanchenko D. G. A Russian Bank in the Khanate of Khiva of Novo-Urgench Branch of the Russo-Asiatic Commercial Bank // Вестник Санкт-Петербургского университета. История. 2020. Т. 65. Вып. 3. С.790-813.

https://doi.org/10.21638/11701/spbu02.2020.306

Хлопководство, как одна из ведущих отраслей экономики Туркестана начала XX в., привлекало внимание крупных инвесторов Российской империи. В советской и современной историографии интерес к деятельности имперских банков на территории Центральной Азии обусловлен продолжающимися дискуссиями о роли и значении российского капитала в экономическом развитии региона. Зачастую для принятия рациональных долгосрочных финансовых решений представителям российского капитала на окраинах нужно было тщательно изучить специфику местной политической ситуации. В статье на основе материалов Российского государственного исторического архива подробно рассмотрено функционирование Ново-Ургенчского отделения Русско-Азиатского коммерческого банка: успешные и неудачные операции, организационная структура, взаимодействие с клиентами, влияние на региональном рынке. Уникальность этого филиала одного из крупнейших русских банков в том, что он был единственным кредитно-финансовым учреждением, развивавшим свою деятельность по всему Хивинскому оазису, включая территории, подконтрольные хивинскому хану. Клиентами и партнерами Ново-Ургенчского филиала банка становились как представители местной политической и экономической элиты, так и предприниматели из Центральной России. Широта связей позволила этому учреждению в короткий срок завоевать и сохранять даже в кризисных условиях свою нишу на рынке финансовых услуг в Центральной Азии. Накануне Первой мировой войны банк принял решение монополизировать хлопковую отрасль, работая с крупными клиентами и даже стимулируя развитие обрабатывающей промышленности. Ново-Ургенчский филиал Русско-Азиатского банка оказывал помощь местному купечеству в попытках увеличить экспорт сырья и выйти не только на общероссийский, но и на международный рынок. В силу объективных причин (нехватка оборотных средств, слабая инфраструктура региона, биржевые колебания, кадровые проблемы) Ново-Ургенчский филиал не смог захватить и контролировать рынок Хивы. В годы Первой мировой войны влияние проблем, характерных для банковского сектора, как и для всей экономики России, в полной мере испытала и среднеазиатская окраина.

Ключевые слова: Русско-Азиатский коммерческий банк, Хивинское ханство, Туркестан, хлопок, Российская империя.

History of banks and banking in Turkestan has barely been researched, and where it has, it mostly shed light upon these aspects within the framework of the Soviet concept of "monopolistic capitalism". Researchers have only fragmentarily studied operations of the 
State bank of the Russian Empire, Russo-Asiatic ${ }^{1}$ and Volzhsko-Kamski banks. It is not possible today to clearly evaluate and characterize activities and functioning of the banks of the Empire in Central Asia on the basis of the works by Soviet and post-Soviet historians as they often contradict contemporary concepts of empire.

According to a famous Soviet historian who researched the topic, A.S. Sadykov, "activities of the financial capital did not transform the character of the commodity-money and credit relationships which existed in Khiva in the past; they only created a certain hierarchy where almost all producers were subject to the banking capital (through middlemen)"2. Given that, Z.D. Kastel'skaia argues "Russian capitalism created a vast system of banks in Turkestan to the end of exploiting the local economy"3.

However, we favour N. B. Khotamov's opinion, characteristic of late Soviet historiography: "Russian financial capital in its colony, the Central Asia... did not provide assistance to the local banks which emerged in the region independently of the Russian ones, and therefore remained weak and did not have a significant influence on the economic life" 4 .

Nowadays, it is difficult to agree with the view that activities of merchants and entrepreneurs were a sign of emergence of "local industrial and commercial bourgeoisie" in the region which held strong economic position, where "connections and strong financial dependence on Russian commercial, industrial and especially banking capital did not allow it to become the monopolist in the commercial and industrial sector"5.

Consequently, all above-stated ideas call for re-interpretation. The analysis of the sources and contemporary historiography on the subject enable to confidently maintain that it was virtually impossible to become a monopolist in the profiteering economy that developed in the Khanate of Khiva.

Establishing routes of communication and building railroads indeed strengthened ties between central parts of the country and its economically backward outskirts, stimulated their involvement in the Russian market, promoted emergence and development of economic sectors (most of all, those related to cotton farming) previously unknown to Russia's Central Asia, and even their entering the international market as T. M. Kitanina

\footnotetext{
${ }^{1}$ Aminov A. M. Ekonomicheskoe razvitie Srednei Azii (Kolonial'nyi period). Tashkent, 1959. P.272; Veksel'man M. I. Rossiiskii monopolisticheskii I inostrannyi kapital v Srednei Azii (konets XIX - nachalo XX v.). Tashkent, 1987. P. 35, 40-50, 62-67, 69-74, 82-83, 85-90, 93, 114-116, 119-120; Gindin I. F. Banki i ekonomicheskaia politika v Rossii (XIX - nachalo XX v.). Izbrannoe. Ocherki istorii I tipologii russkikh bankov. Moscow, 1997; Istoriia Uzbekskoi SSR / eds by M. G. Vakhabova, V. Ia. Nepomnina, T. N. Kary-Niiazova. Vol. 1, book 2. Tashkent, 1956. P. 207-208; Kitanina T. M. Voenno-infliatsionnye kontserny v Rossii 1914-1917 gg. Kontsern Putilova-Stakheeva-Batolina. Leningrad, 1969; Pogorel'skii I. V. Ocherki ekonomicheskoi i politicheskoe istorii Khivinskogo khanstva kontsa XIX - nachala XX v. (1873-1917 gg.). Leningrad, 1968. P.92; Potapova N. Yu. Istoriia predprinimatel'stva v Turkestane (vtoraia polovina XIX - nachalo XX v.). Tashkent, 2011. P.74-76, 91; Sadykov A. S. Rossiia i Khiva v kontse XIX - nachale XX veka. Tashkent, 1972; Iuldashev A. M.: 1) Proniknovenie russkogo monopolisticheskogo kapitala v ekonomike Turkestana (1900-1917 gg.): avtoref. diss. ... kand. ekon. nauk. Tashkent, 1961; 2) Agrarnye otnosheniia v Turkestane (konets XIX - nachalo XX v.). Tashkent, 1970. P. 124-126, 208-217, 219-221.

2 Sadykov A. S. Ekonomicheskie sviazi Khivy s Rossiei vo vtoroi polovine XIX - nachale XX v. Tashkent, 1965. P. 153.

${ }^{3}$ Kastel'skaia Z. D. Iz istorii Turkestanskogo kraia (1865-1917). Moscow, 1980. P. 64.

${ }^{4}$ Khotamov N. B. Rol' bankovskogo kapitala v sotsial'no-ekonomicheskom razvitii Srednei Azii (nachalo 90-kh gg. XIX v. - 1917 g.). Dushanbe, 1990. P. 4.

${ }^{5}$ Makhkamova N.R. Sotsial'naia struktura obshchestva na territorii Uzbekistana: traditsii i transformatsii (konets XIX v. - 30-e gody XX v.). Tashkent, 2009. P. 26.
} 
points out ${ }^{6}$. However, it was mostly true for the regions where the Russian government system and law were predominant.

As evidenced by the archival documents on the branches of the Russo-Asiatic bank, we argue that credit operations of the institution in the Khivan oasis promoted profiteering in the local markets more than development of processing industry which, of course, held back fast modernization of economy. Let us consider these processes as exemplified by the work of a unique banking system, the Novo-Urgench branch of the Russo-Asiatic commercial bank in the khanate of Khiva and neighbouring regions of Governorate-General of Turkestan.

The Russo-Asiatic commercial bank (RACB. - Authors' note) (prior to 1910, it was called the Russo-Chinese bank) was considered the largest bank in the region; it had a vast network of 13 branches around Central Asia ${ }^{7}$. In its operations, the Russo-Asiatic bank attempted to have control over, indeed, cotton farming and industrial production. Modernization of economy of Central Asia, according to the understanding of the bank's administration, obviously lay in financing of export crops and intermediate trade between the central regions and the periphery. In the context of the Russian colonization of Turkestan, and a project of reclamation of Mirzacho'l (lit. "hungry steppe") that never came to life $^{8}$, functioning of RACB in Khiva could be seen as an alternative, commercial approach to establishing economic dominance of the empire's central power over Central Asia.

Economic position of the Khanate of Khiva and interests of the Novo-Urgench branch of the Russo-Asiatic commercial bank. The Novo-Urgench branch of the Russo-Asiatic commercial bank was the only lending and financial institution which attempted to develop its operations around the entire oasis of Khiva. Commercial interests of the Novo-Urgench branch extended over Khivan territory proper with its towns and kishlaks - Khiva, Urgench, Khanki (currently settlement of Xonqa, Uzbekistan), Hazorasp, Tashauz (currently town of Daşoguz, Turkmenistan), Mangit - altogether home to approximately 1 million people, and the Amu-daria branch with its towns and kishlaks - Petroaleksandrovsk (currently town of To'rtko'l, Uzbekistan), Shurakhan, Gurlyan (currently settlement of Gurlen, Uzbekistan), Khodzhent (currently town of Khudzhand, Tadzhikistan), Chimbai, Akhbugut (in the estuary of the Amu-daria) - altogether home to approximately 600 thousand people 9 .

Cotton farming was the key pillar of the economy of the region - a field that unalterably enjoyed support of the tzar's government in Turkestan. However, in 1906, according to the state controller P.H. Schwanebach, cotton farming became more profitable than all other crops in the region and was so developed that the existing benefits could be can-

${ }^{6}$ Kitanina T. M. Proniknovenie krupnogo rossiiskogo finansovogo kapitala v ekonomiku Srednei Azii v kontse XIX — nachale XX v. St. Petersburg, 2019.

7 Salomatina S.A. Rossiiskie i sovetskie banki v stranakh Srednego i Dal'nego Vostoka 18901920-e gg.: transformatsiia imperskikh traditsii // Ekonomicheskaia istoriia: ezhegodnik. 2014. Vol.2013. P. 568-624; Sokolov V. V. Kolonial'nyi Turkestan: ekonomiko-promyshlennoe sostoianie i razvitie. Moscow, 2002.

8 Mamaev A. V. Imperskii proekt zaseleniia Golodnoi stepi // Quaestio Rossica. 2019. Vol.7, no. 4. P. 1259-1274.

9 Perepiska Upravleniia otdeleniiami s Novo-Urgenchskim otdeleniem banka o sostoianii mestnogo rynka i osnovnykh napravleniiakh deiatel'nosti otdeleniia, ob organizatsii Otdeleniem eksporta liutserny cherez Gamburgskuiu birzhu, o popytke sozdat' sindikat skupshchikov liutserny dlia ustraneniia konkurentsii, 1911 g. // Rossiiskii gosudarstvennyi istoricheskii arkhiv (RGIA). F. 630. Op. 1. D. 475. L. 64 ob.-65. 
celled $^{10}$. That opinion was perhaps induced by the events of the Russian revolution of 1905 and a resulting tendency of the Russian government to strengthen its influence over the periphery. In this context, taking into account the special status of the Khanate of Khiva in the Russian Empire, operations of the Russian commercial structure in what concerns monopolization of the cotton market are of special interest.

In the years of 1910 and 1911, approximately 850 thousand of pudi of cotton fibre totaling 12 million roubles was produced in the Khanate of Khiva. Purchase and export of cotton was mainly carried out by Yaroslavskaia Bolshaia Manufaktura (manufacture), Moskovskoe torgovo-promyshlennoe tovarishchestvo (business association), trading house "Stuken and $\mathrm{K}^{\circ}$ ", brothers Kraft, oilery and techno-chemical plant of Z. M. Persitz, Y.M. Shlossberg. Novo-Urgench branch of the Russo-Asiatic bank bought up more than $20 \%$ of all cotton in $1910 / 11^{11}$. Local and international profiteers, merchants and manufacturers also bought raw material.

There were 23 cotton-ginning factories in the Khivan khanate, 5 of which were in Petroaleksandrovsk (they were owned by P. A. Manuilov, A. Ravilov, Chaubanov, Samandarov, Dzhalekov and Mad'iarov); 4 factories were located in Urgench and belonged to Yaroslavskaia manufaktura, K. A. Manuilov, S. Bakkalov and a Khivan company; 3 factories were situated in Gurlyan and owned by the Rizaev brothers, P.A.Manuilov and B. Maksutov; 3 factories in Tashauz belonged to Yaroslavskaia manufaktura, the Chernikov and S. Bakkalov; 2 factories were found in Hazorasp and owned by S. M. Aminov and S. Bakkalov, and one factory in Mangit belonged to K. A. Manuilov. There were three oileries: P. A. Manuilov was the owner of two factories in Petroaleksandrovsk and Khanki, Yaroslavskaia manufaktura and an oilery in Urgench. All oil was sold for local use ${ }^{12}$.

In 1911, up to 400 thousand pudi of alfalfa to the amount of 3 million roubles was exported from Khiva, more than one third of which - by the Urgench branch. "Apart from our bank", noted A. Slutskii who inspected the Novo-Urgench branch of RACB, "alfalfa was also purchased by Kraft, the Rizaev brothers, Karnel', the Chernikov brothers, etc. About 500 thousands of karakul pelts are exported from Urgench district with the sum total up to 4 million roubles ${ }^{13}$ ". Up to 30 thousand pudi amounting to 200 thousand roubles were exported. The list of goods intended for export from the Khivan khanate going through Urgench was concluded by leathers, meshis (leather bags) and intestines.

The structure of import to the region remained considerably traditional. Manufactured goods were on top of the list with, according to Slutskii's estimate, "up to 200 thousand pudi totaling around 8 million roubles, followed by 200 thousand pudi of castor and lump sugar totaling around 1 million roubles"14. Circa 150 thousand pudi of kerosene totaling 300 thousand roubles were imported into the region.

Prior to the intensive activity developed by RACB in the region, Cossacks from the Urals who had been forcefully relocated to the Amu-daria division for avoiding Orthodoxy were the influential trading element. A. Slutskii noted the following: "Kerosene trading is in the hands of Uralians, but they will probably lose it as they have lost sugar. About

${ }^{10}$ Mamaev A. V. Podgotovka reform pravleniia Turkestanskim kraem v nachale XX v.: Ekonomicheskie aspekty // Nauchnyi dialog. 2019. No.11. P.391.

11 RGIA. F. 630. Op. 1. D. 475 . L. 64 ob.-65.

12 Ibid.

13 Ibid.

14 Ibid. 
60 thousand pudi of green tea to the amount of 1,5 million roubles is imported. The trade is in the hands of Persians, mainly the Rizaev brothers" 15.

During the first decade of the $20^{\text {th }}$ century, control over the market passed into the hands of agents of transport companies, branches of the Russo-Asiatic bank, and large reselling entrepreneurs. The increasing influence of representatives of large capital appears to have been an all-Russian tendency that involved the periphery as well. The volume of both import and export sales were estimated by analysts of the Russo-Asiatic bank at 3 million pudi (48 900 tons), however the technical provision of import and export operations left much room for improvement.

Almost all goods were transported over Chardzhui "in kayuks, of which there are around 300 in the Amu-daria, each with the capacity between 1500 and 2000 pudi. A small proportion of goods is transported via the Aral Sea by the shipping agency 'Khiva' (ill-equipped, for that matter)"16, Slutskii wrote. When the Amu-daria froze up, insignificant part of goods was sent via Chardzhui (currently town of Turkmenabad, Turkmenistan), Asgabat (currently town of Ashgabat, Turkmenistan) and Krasnovodsk (currently town of Turkmenbashi, Turkmenistan - auth.), but such means of transportation were expensive and risky. Evidently, the complicated logistics and underdeveloped transport infrastructure were, as in most other peripheral regions, a substantial obstacle on the way to economic modernization.

Main operations of the Novo-Urgench branch of the Russo-Asiatic bank. The Novo-Urgench branch of the Russo-Asiatic bank was founded in 1909. The first director of the bank was V.Y. Komarovskii (from 1909 until 1911), a former employee of the Poznanskii broth $^{17}$. Initial capital (opening balance) as of 1 January1910 was approximately 4 million 100 thousand roubles ${ }^{18}$, and by 1 January 1917 the opening balance had decreased and amounted to 3622561 roubles 03 kopecks $^{19}$, which in our view was connected with the development of crisis in the Russian banking system which manifested itself in the years of the First World War.

In 1911, the main branch of the Russo-Asiatic bank assigned the Novo-Urgench branch with a constant capital of 1 million roubles ${ }^{20}$. "We believe", reported the administration of the branch back to Saint Petersburg, "that one million roubles assigned to our branch should be far from enough. Apart from what we invested in alfalfa, the amount will only be enough for our main operations. We should think that we shall need 1 million roubles of constant capital and an additional capital of 1 million roubles"21.

The bank provided its branch with another 800 thousand roubles, but even that was not enough. I. I. Fruhling (director of the branch from 1911 until1 916) considered it impossible to "renew the last year's agreement with Mr. Mad'iarov and Mr. Bakkalov (both were in the khan's coterie and even accompanied him in his travel to Saint Petersburg. Authors' note) in case of realization of the idea of syndication (here: cooperative opera-

15 Ibid.

16 Ibid.

17 Ibid. L. 85-90.

18 Otchety Novo-Urgenchskogo otdeleniia banka za 1910-1917 gg. // RGIA. F. 630. Op. 1. D. 474. L. $16 \mathrm{ob}$.

19 Ibid. L. 158 ob.

${ }^{20}$ Ibid. L. 210-212.

${ }^{21}$ Ibid. 
tions. - Authors' note) of the Khivan market by alfalfa exporters. And in that case, we shall need a capital of at least half a million roubles" 22 .

In 1911, the bank attempted monopolization of the Khivan market but the idea to unite all large firms under the umbrella of the branch failed. The main reason for the failure of the "syndication" was, according to I. I. Fruhling, "high prices for alfalfa in Khiva and the expected fair yield in France"23.

The main active operations of the bank were negotiation of bills (Table 1), acceptance credits and term loans. For negotiation of bills, Bill negotiation committee was created; in 1911, a representative of interests of a group of Persian traders and manufacturers and an authorized person of the trading house of the Rizaev brothers, K. A. Aliev, was invited ${ }^{24}$. Operations with bills, as stated by the administration of the bank, were not developed to the level of the cotton-farming districts of the Ferghana region of the Governorate-general of Turkestan. Negotiation of bills, according to the opinion of V. Y. Komarovskii, yielded "profit rather insignificant and unstable. Operations of that linear eanaemic and could not be developed due to the nature of the local production sector and underdevelopment of bills of exchange among the local population who recourse, as required by Sharia, to performance of cadikhat, which is not accepted by the bank" 25 .

Table 1. Active (bill) operations of the Novo-Urgench branch of the Russo-Asiatic bank, roubles ${ }^{26}$

\begin{tabular}{|c|c|c|c|}
\hline Year & Total turnover & $\begin{array}{c}\text { Bills of exchange were } \\
\text { recorded }\end{array}$ & $\begin{array}{c}\text { Received sums from } \\
\text { exchanged bills }\end{array}$ \\
\hline 1910 & 61011475,49 & 272592,60 & 11076,55 \\
\hline 1911 & 91008142,24 & 684835,55 & 19506,65 \\
\hline 1912 & 98327924,86 & 902579,01 & 40875,26 \\
\hline 1913 & 92189804,58 & 793981,85 & 38773,51 \\
\hline 1914 & 86981251,44 & 638764,58 & 29161,94 \\
\hline 1915 & 156115323,34 & 327976,18 & 19277,03 \\
\hline 1916 & 211994574,50 & 127450,00 & 6410,98 \\
\hline 1917 & 418754157,58 & 92300,00 & 2889,93 \\
\hline
\end{tabular}

Apparently, the traditional system of debt instruments of "bill" type was maintained in Khiva and widely used by the local population. One could challenge the cadi's decisions (and cadi received at least 1,5\% of a deal) with khan, which, of course, was not acceptable for the bank acting in accordance with the Russian legislation.

The data above shows that bill negotiation peaked at 1912 and 1913, and soon began to decrease due to the bad condition of the bank's bill portfolio. Since 1911, the Novo-Ur-

22 Otchety Novo-Urgenchskogo otdeleniia banka za 1910-1917 gg. L. 239-241.

23 Ibid. L.248-249.

${ }^{24}$ Ibid. L. 42.

25 Ibid. L. 85-90.

26 Ibid. L. 2, 16 ob., 18, 35 ob., 37, 62 ob., 64, 82 ob., 84, 107 ob., 109, 131 ob., 133, 158 ob., 160. 
gench branch began to negotiate promissory notes by the order of the administration although I.I. Fruhling did not approve of that operation. In his correspondence with the bank's administration, he aired grievances regarding "large disincentive for successful collection of cotton consignment and absolute requirement to demand promissory notes from clients prior to issuing loans against transport documents. The formality literally drives the Khivan client away since he is used to going without it when dealing with Stuken and Torgopro (the Moscow business association. - Authors' note)"27. In 1913, the operation was approved by the bank's administration (Table 2).

Table 2. Negotiation of promissory notes, roubles $^{28}$

\begin{tabular}{|c|c|c|}
\hline Year & Exchanged & Received \\
\hline 1913 & 135500,00 & 4004,05 \\
\hline 1914 & 11000,00 & 188,37 \\
\hline 1915 & 5500,00 & 230,31 \\
\hline 1916 & - & - \\
\hline 1917 & - & - \\
\hline
\end{tabular}

In the autumn of 1911, the bank raised interest charges for all bill and commodity operations to $10 \%$ p.a. This was done to the effect of "liberation from small and uninteresting clientele" and the said effect was mainly achieved by the refusal to accept bills from such clients ${ }^{29}$.

The bank's principal income was from on-call loans (see Table 3).

Since 1914, the bank began to supply on-call loans against security papers, which by 1916 had accrued almost 167 thousand roubles but, for reasons well-known, the number fell down in 1917. Table 3 shows that the number of on-call loans against goods and railway bills of lading was constantly growing, which is attributed to the growth of steady export to the European Russia and Western Europe. It is to be noted that during the World War I, the number of on-call loans against bills was decreasing, while loans against goods were growing; this is accounted for by stock-exchange manipulations and inflation. By May 1916, commodity operations of the branch amounted to 690 thousand roubles. The amount was comprised by the following: against cotton, 498 thousand roubles (72\%), against tea -116 thousand roubles (17\%), against alfalfa -34 thousand roubles (5\%), against sugar, manufactured products, etc. -42 thousand roubles $(6 \%)^{30}$.

The Novo-Urgench branch of the Russo-Asiatic bank also developed the business line of term loans (Table 4).

27 Perepiska Upravleniia otdeleniiami s Novo-Urgenchskim otdeleniem banka o sostoianii mestnogo rynka i osnovnykh napravleniiakh deiatel'nosti Otdeleniia, ob organizatsii otdeleniem eksporta liutserny cherez Gamburgskuiu birzhu, 1911-1916 gg. // RGIA. F. 630. Op. 1. D. 476. L. 103-106, 108-109.

28 RGIA. F. 630. Op. 1. D. 474. L. 64, 84, 109.

${ }^{29}$ Ibid. D. 476. L.26-27.

30 Otchet inspektorov banka B.Lukod'ianova i R. Tal'ma o revizii deiatel'nosti Novo-Urgenchskogo otdeleniiana 16 maiia 1916 g. Direktor I. I. Friuling // RGIA. F. 630. Op. 1. D. 480. L. 9 ob.-10 ob. 
Table 3. Active operations (on-call loans) of the Novo-Urgench branch of the Russo-Asian bank, roubles ${ }^{31}$

\begin{tabular}{|c|c|c|c|c|c|c|}
\hline Year & $\begin{array}{c}\text { Issued under } \\
\text { security of } \\
\text { values }\end{array}$ & $\begin{array}{c}\text { Received } \\
\text { from this } \\
\text { operation }\end{array}$ & $\begin{array}{c}\text { Issued under } \\
\text { the goods }\end{array}$ & $\begin{array}{c}\text { Received from } \\
\text { this operation }\end{array}$ & $\begin{array}{c}\text { Issued under } \\
\text { security of bills }\end{array}$ & $\begin{array}{c}\text { Received } \\
\text { from this } \\
\text { operation }\end{array}$ \\
\hline 1910 & - & - & 2740481,27 & 52667,74 & 866320,09 & 16775,53 \\
\hline 1911 & - & - & 2499116,89 & No data & 629075,49 & No data \\
\hline 1912 & - & - & 3451241,98 & 158475,34 & 667983,08 & 39695,85 \\
\hline 1913 & - & - & 2437353,14 & 87990,74 & 731309,50 & 33158,76 \\
\hline 1914 & 74615,88 & 710,20 & 2513245,00 & 83839,52 & 491942,62 & 30216,72 \\
\hline 1915 & 59579,30 & 3241,67 & 3485469,62 & 62152,81 & 462410,47 & 19762,91 \\
\hline 1916 & 166903,99 & 5539,51 & 3923615,45 & 63976,19 & 665386,48 & 9252,16 \\
\hline 1917 & 3779,71 & 2887,12 & 3681193,99 & 69955,16 & 4718797,75 & 24304,07 \\
\hline
\end{tabular}

Table 4. Active operations (term loans) of the Novo-Urgench branch of the Russo-Asiatic bank, roubles ${ }^{32}$

\begin{tabular}{|c|c|c|c|c|}
\hline Year & $\begin{array}{c}\text { Issued under security } \\
\text { of values }\end{array}$ & $\begin{array}{c}\text { Received from this } \\
\text { operation }\end{array}$ & $\begin{array}{c}\text { Issued under the } \\
\text { goods and documents }\end{array}$ & $\begin{array}{c}\text { Received from this } \\
\text { operation }\end{array}$ \\
\hline 1910 & 3422,00 & 156,25 & 233970,00 & - \\
\hline 1911 & 15660,16 & No data & 516759,43 & No data \\
\hline 1912 & 5626,00 & 411,78 & 287217,55 & 9357,98 \\
\hline 1913 & 3726,70 & 497,33 & 61107,65 & 7750,20 \\
\hline 1914 & 2350,72 & 530,52 & 15280,47 & 8685,47 \\
\hline 1915 & 1100,00 & 679,78 & 56,46 & 5,46 \\
\hline 1916 & 20864,58 & 590,80 & 740318,99 & 5136,27 \\
\hline 1917 & 118134,10 & 3462,48 & 876700,81 & 16405,59 \\
\hline
\end{tabular}

Term loans were issued by banks mainly against goods and trade documents. Loans were issued in the amount of $80 \%$ of the total price of goods, and advances were secured by clients' bills in hand ${ }^{33}$. Loans were mainly issued against cotton, alfalfa and tea. The decrease in term loans against goods in 1913 and 1914 is accounted for by the situation on stock exchange and bankruptcy of merchants. For instance, in 1913 the trading house of the Rizaev brothers, one of the largest vendors of tea (see Table 5) went bankrupt. Con-

31 RGIA. F. 630. Op. 1. D. 474. L. 3 ob.-4; 20 ob. $-21 ; 39$ ob. $-40 ; 66$ ob. $-67 ; 86$ ob.-87; 111 ob.-112; 135 ob.-136; 162 ob.-163.

32 Ibid. L. 3 ob. $-4,22,41,68,88,113,137,164$.

${ }^{33}$ Ibid. D. 475. L. 44-48. 
sequentially, two branches of the Russo-Asiatic bank suffered: the Samarkand and the Novo-Urgench.

Table 5. Debts of the Rizaev brothers on 01.11.1913, roubles $^{34}$

\begin{tabular}{|l|c|c|c|c|}
\hline \multirow{2}{*}{ Town } & \multicolumn{2}{|c|}{ On-call under bills } & \multicolumn{2}{c|}{ On-call under goods } \\
\cline { 2 - 5 } & Debt & $\begin{array}{c}\text { Under the } \\
\text { guaranteed bills }\end{array}$ & Debt & $\begin{array}{c}\text { Under the } \\
\text { guaranteed goods }\end{array}$ \\
\hline Samarqand & 57377 & 72691 & 303437 & 255932 \\
\hline Novo-Urgench & 197265 & 260538 & 233015 & 189235 \\
\hline Total & 254642 & 333229 & 536452 & 445167 \\
\hline
\end{tabular}

As a result of the agreement between the bank and the firm, bill debt payment was broken down into installment plan for 6 years, and the debt was secured by the firm's real estate mortgage valued at 200 thousand roubles $^{35}$. Despite all effort, the Rizaev brothers could not pay their debts to the bank. By 1 July 1917 their debt amounted to almost 250 thousand: 144372 roubles 46 kopecks (on-call against bills) and 105436 roubles 43 kopecks (on-call against trading documents) ${ }^{36}$.

Apart from the trading house of the Rizaev brothers, other large regional entrepreneurs were bill debtors to the Novo-Urgench branch of the Russo-Asiatic bank (Table 6).

Table 6. Statement of debt secured against real estate on 01.12.1913, roubles $^{37}$

\begin{tabular}{|c|c|c|c|}
\hline Client & Debt & Account & Mortgages \\
\hline Abdal Iusupov & 25000,00 & Bearer accounting & $\begin{array}{c}\text { Copy of the mortgage } \\
\text { for 50 thousand rubles }\end{array}$ \\
\hline$-/ /-$ & 5700,00 & On-call for goods & - \\
\hline Yu. Aitbaev & 26000,00 & Bearer accounting & 5400 \\
\hline$-/ /-$ & 2000,00 & Accounting for promissory notes & 90000 \\
\hline$-/ /-$ & 39883,54 & On-call for goods & 18000 \\
\hline$-/ /-$ & 4956,97 & Merchandise Debit & 36000 \\
\hline$-/ /-$ & 22345,55 & Urgent loans for goods & \\
\hline
\end{tabular}

In 1916, the bank sold its property, including Yu. Aitbaev's factory for 31661 roubles 39 kopecks, thus partly covering losses.

${ }^{34}$ Ibid. D. 476. L. 171; D. 477. L. 42.

35 Ibid. D. 476. L. 171.

36 Perepiska otdela nedvizhimykh imushchestv s Novo-Urgenchskim otdeleniem o sostoianii schetov klientov po kreditam, obespechennym zakladnymi na nedvizhimoe imushchestvo, s prilozheniiami vedomostei o nedvizhimom imushchestve, 1913-1917 gg. // RGIA. F. 630. Op. 1. D. 477. L. 42.

37 Ibid. L. 8. 
For the period concerned, the main data for the bank's active operations are given in Tables 7 and 8 .

Let us consider balance in hand for active operations at the beginning of each year in 1910-1916 (Table 8).

Table 7. Main operations flow in 1909-1915, roubles $^{38}$

\begin{tabular}{|c|c|c|c|}
\hline Year & Issuance of bill transactions & Commodity Transactions & Write-offs at a loss \\
\hline 1909 & 435000 & 1839000 & - \\
\hline 1910 & 1139000 & 2978000 & 6400 \\
\hline 1911 & 1314000 & 3032000 & 12200 \\
\hline 1912 & 1570000 & 3744000 & 20900 \\
\hline 1913 & 1576000 & 2507000 & 37800 \\
\hline 1914 & 1129000 & 2605000 & 13100 \\
\hline 1915 & 797000 & 3546000 & - \\
\hline 1.06 .1916 & 110000 & 1444000 & 90400 \\
\hline Total & 8070000 & 21695000 & \\
\hline
\end{tabular}

Table 8. Main operations flow, roubles ${ }^{39}$

\begin{tabular}{|c|c|c|}
\hline Balance & On bill transactions & For commodity operations \\
\hline 01.01 .1910 & 255000 & 653000 \\
\hline 01.01 .1911 & 598000 & 1480000 \\
\hline 01.01 .1912 & 959000 & 1914000 \\
\hline 01.01 .1913 & 884000 & 1742000 \\
\hline 01.01 .1914 & 961000 & 1544000 \\
\hline 01.01 .1915 & 793000 & 1016000 \\
\hline 11.06 .1916 & 312000 & 556000 \\
\hline
\end{tabular}

It is to be noted that by 1916, active operations of the branch comprised only around 800 thousand roubles ${ }^{40}$, which did not cover the bank's expenses.

Passive operations of the Novo-Urgench branch of the Russo-Asiatic bank. With each passing year, the branch developed passive operations more and more: deposits on current accounts increased, on-demand deposits decreased, and term loans showed steady growth since 1912 (Tables 9 and 10).

\footnotetext{
${ }^{38}$ RGIA. F.630. Op. 1. D. 480. L. 7 ob.

39 Ibid.

${ }^{40}$ Ibid. L. 17 ob.
} 
Table 9. Passive operations (deposits) of the Novo-Urgench branch of the Russo-Asiatic bank, roubles ${ }^{41}$

\begin{tabular}{|c|c|c|c|c|c|c|}
\hline Year & $\begin{array}{c}\text { To current } \\
\text { accounts } \\
\text { accepted }\end{array}$ & Claimed & $\begin{array}{c}\text { Term } \\
\text { deposits } \\
\text { accepted }\end{array}$ & Claimed & $\begin{array}{c}\text { Term deposits } \\
\text { accepted }\end{array}$ & Claimed \\
\hline 1910 & 6378486,40 & 6216300,20 & 239828,00 & 227828,00 & 292178,00 & 253828,00 \\
\hline 1911 & 5770023,23 & 5856755,36 & 53350,00 & 50350,00 & 28600,00 & 53350,00 \\
\hline 1912 & 5582600,34 & 5392386,07 & 7000,00 & 22000,00 & 69000,00 & 71600,00 \\
\hline 1913 & 6578415,10 & 6558026,76 & 92350,00 & 55000,00 & 92400,00 & 21000,00 \\
\hline 1914 & 4680740,00 & 4801001,64 & 16000,00 & 65350,00 & 162100,00 & 224400,00 \\
\hline 1915 & 12884967,49 & 12423427,23 & 70367,38 & 51367,38 & 428350,00 & 404100,00 \\
\hline 1916 & 16509121,88 & 15668271,64 & 84000,00 & 4000,00 & 731204,18 & 449241,66 \\
\hline 1917 & 32027471,55 & 32364899,07 & - & 99000,00 & 742572,94 & 685885,46 \\
\hline
\end{tabular}

Table 10. Balance in hand of deposits and current accounts, roubles ${ }^{42}$

\begin{tabular}{|c|c|}
\hline Year & Overall balance \\
\hline 01.01 .1910 & 240362 \\
\hline 01.01 .1911 & 452898 \\
\hline 01.01 .1913 & 517030 \\
\hline 01.01 .1914 & 668168 \\
\hline 01.01 .1915 & 436257 \\
\hline 01.01 .1916 & 941047 \\
\hline 16.05 .1916 & 1723875 \\
\hline 13.06 .1916 & 2360462 \\
\hline
\end{tabular}

Deposits to the bank increased sharply in 1916 and, according to an inspector, the result "surpassed all expectations: over 5 months and several days, deposits had grown by $151 \%$ and, even during our inspection, the increase in deposits was $37 \%$ " 43 .

Interest rates and the number of deposits in the bank depended on the increase in prices for export goods and successful suppression of Turkmen uprising. The biggest deposits and current accounts as per 16 May 1916 belonged to the Khivan khan, 150 thousand roubles with 5,5\% p.a.; K. Babadzanov, 158915 roubles with 5,5\% p.a.; M. K. Tadziniiazov, 113 thousand roubles with 3,5\% p. a.; A. Mad'iarov, 70140 roubles with 3 p. a. \%; K.Abduldzabbarov, 51682 roubles with 3 p.a. \%; K.A. Manuilov, 50803 roubles with

\footnotetext{
${ }^{41}$ Ibid. D. 474. L. 8, 26, 45, 72, 92, 119, 143, 168.

${ }^{42}$ Ibid. D. 480. L. 29 ob. -31 ob.

43 Ibid.
} 
3 p. a. \%; M. Avezniiazmatov, 50 thousand roubles with $6 \%$ p. a.; A. Ischanov, 50 thousand roubles with $5,5 \%$ p. a. Aggregate capital of these clients constituted $40 \%$ of all deposits and current accounts (694540 roubles). The average interest rate for deposits and current accounts in 1915 was 3,66 \% p. a., and as per 16 May 1916 it was 3,89\% p.a. ${ }^{44}$ The increase in the number of deposits influenced the bank's administration policy; it began to take loans from the branch. By June 1916, the administration owed the branch almost 1,5 million roubles ${ }^{45}$.

Transfers and correspondent accounts should also be considered successful: in 1911,3048668 roubles 68 kopecks were debited; 3429486 roubles 07 kopecks were credited, and by 1917, 18828689 roubles 12 kopecks were debited; 18757924 roubles 90 kopecks were credited ${ }^{46}$.The Novo-Urgench branch ordered goods for its clients through other branches: the Rizaev brothers paid for tea through the offices of the Samarkand branch of the Russo-Asiatic bank; small firms paid through the offices of the Moscow branch and could order manufactured goods, honey, silver and different gold coins (imperials, Turkish liras $)^{47}$. In consequence of direct debit operations, transfers and letters of credit, the profit grew (Table 11).

Table 11. Direct debit, transfer, letters of credit, roubles ${ }^{48}$

\begin{tabular}{|c|c|}
\hline Year & Incasso, transfers and letters of credit \\
\hline 1909 & 10126 \\
\hline 1910 & 22957 \\
\hline 1911 & 15562 \\
\hline 1912 & 19578 \\
\hline 1913 & 15915 \\
\hline 1914 & 15188 \\
\hline 1915 & 43180 \\
\hline
\end{tabular}

During the World War I, the branch mainly sold war bonds. "On-calls for 145 thousand roubles, secured exclusively against war bonds", inspectors wrote in 1916, "primarily the last one (State $5 \frac{1}{2} \%$ short-term war loan of 1916. - Authors' note); the margin is between 6 and $8 \%$. Term loans and buy and sell account for only 8 thousand roubles - only lottery-bearing bonds" 49 .

In 1915, the Novo-Urgench branch owned 725 shares of the "Emba Caspian Oil Company, Limited"; 41 shares of the Putilov plant, 24 shares of the Russo-Asiatic bank ${ }^{50}$. Despite the economic growth incidental to the war needs, stock exchange operations were slow to develop in the Khivan khanate and Governorate-general of Turkestan.

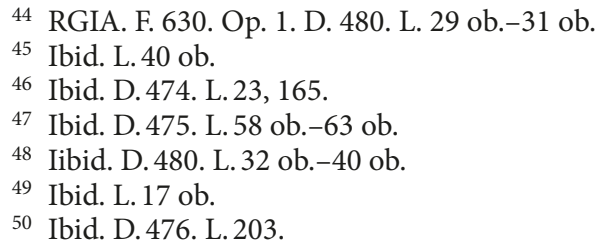


Commodity operations of the Novo-Urgench branch of the Russo-Asiatic bank. From 1910, the bank attempted, through its branches, to trade alfalfa and cotton at foreign markets at its own expense (mainly in Moscow and Hamburg). Cotton was purchased (for the amount of up to 3 million roubles) by the Novo-Urgench branch "a meta" (from Italian "a meta", i. e. half-and-half or fifty-fifty. - Authors' note) with the Moscow branch of the Russo-Asiatic branch, and alfalfa was bought "a meta" with Mad'iarov and Bakkalov for the amount of up to 1,5 million roubles ${ }^{51}$.

Cotton was bought by the bank's branch through intermediary merchants I. I. Pershin in Petroaleksandrovsk, Hazorasp and Shurakhan, T. Piskunov - in Urgench, I. Karmanov - in Thashauz. In Gurlyan, cotton was purchased through the agency of the trading house of the Rizaev brothers "ameta" 52 .

Inspector A. Slutskii pointed out in 1911 that "ill-written contract with Mad'iarov and Bakkalov left, first of all, much room for misuse in the course of purchasing alfalfa" 53 . Mad'iarov and Bakkalov, despite buying "118 thousand pudi, reported purchases only several times, given that Mad'iarov's average buying price is 17 kopecks more per pood than ours, and Bakkalov's - 13 kopecks more than ours" 54 . The inspector noted that "all was bought at the bank's expense" ${ }^{55}$ although, according to the contract, they participated nominally in profit and loss at $55 \%{ }^{56}$.

Slutskii took notice of the "good relationship" established between the branch's director Komarov and Bakkalov and Mad'iarov as well as of the "trust that both had in him [the director]", although "through certain misunderstanding in the course of alfalfa payment calculations", the clients "appeared to have developed some kind of suspicion towards the bank's actions" 57 . Slutskii recommended to revise contracts with Bakkalov and Mad'iarov in the interests of the Novo-Urgench branch and continue operations with alfalfa ${ }^{58}$. A total of 144169 pudi 15 pounds (approximately 2 million 363 thousand tons and 720 kilograms. - Authors' note) of hulled alfalfa were bought together with these partners, out of which 77261 pudi 25 pounds (approximately 1 million 266 thousand tons and 740 kilograms. - Authors' note) with book value of 684371 roubles 60 kopecks, i. e. around 8,71 roubles for pood franco-Urgench.

During 1911, goods for the total value of 854204 roubles 29 kopecks were bought at the expense of the branch and sold for the total of 1179513 roubles 85 kopecks ${ }^{59}$. Despite the positive development of the branch's commodity operations in 1911, the negative profit from cotton trading was 234342 roubles 91 kopecks $^{60}$, and the total value of goods not sold 766031 roubles $^{61}$. The negative tendency continued in the years to follow (see Table 12).

\footnotetext{
51 Ibid. D. 475. L. 56-58.

52 Ibid. L. 58 ob. -63 ob.

53 Ibid.

54 Ibid.

55 Ibid.

56 Ibid.

57 Ibid.

58 Ibid. L. 67 ob. -68 ob.

59 Ibid. D. 474. L. 25.

60 Ibid.

61 Ibid.
} 
Table 12. Commodity operations of the bank's branch, roubles ${ }^{62}$

\begin{tabular}{|c|c|c|c|c|}
\hline Year & $\begin{array}{c}\text { Purchased goods at } \\
\text { your own expense }\end{array}$ & Sold items & Balance & Loss/profit \\
\hline 1911 & 854204,29 & 1179513,85 & 766031,00 & $-234342,91$ \\
\hline 1912 & 67253,04 & 831109,42 & 2174,98 & $-33947,77$ \\
\hline 1913 & - & - & - & - \\
\hline 1914 & 15180,00 & 11096,40 & 7493,95 & $+2566,28$ \\
\hline 1915 & 3558,20 & 10764,75 & 287,40 & $+3492,19$ \\
\hline 1916 & - & - & - & - \\
\hline 1917 & - & - & - & - \\
\hline
\end{tabular}

In 1911-1913, cotton and alfalfa operations were influenced by the difficult environment at Moscow and Hamburg stock exchanges, whereupon the bank sustained substantial losses. Apart from the negative conditions at stock exchanges, 70 carloads of alfalfa could not be dispatched because of the early winter of $1911^{63}$. In March 1911, the director of the Novo-Urgench branch V.Y.Komarovskii, asked the administration of the Russo-Asiatic commercial bank for permission to proceed to Hamburg to the end of solving the alfalfa stock exchange sale issue. In order to reduce expenses, Komarovskii suggested that administration should sell alfalfa to America or that firms should buy it on a commission basis ${ }^{64}$. It is noteworthy that the director attributed failures in trade operations exclusively to the early winter and bad infrastructure of the khanate of Khiva. V. Y. Komarovskii also recommended that the branch should buy cotton in the region directly. We can assess the risks of such operation from the letter written by F. Miliashkevich, who managed the Samarkand branch, to the Moscow branch of the Russo-Asiatic commercial bank. At the end of March 1911, he complained about transport companies ("Vostochnoye", "Kavkaz I Mercuriy") which failed to apply enough care to the transportation of cotton resulting in the deteriorated quality of the material and corresponding lower prices on stock exchange. Given that, transport companies charged 3 kopecks per each pood in order to "cover goods with tarpaulin", which had no effect but increased the final price ${ }^{65}$.

Following A. Slutskii revision, the Novo-Urgench branch of the bank drastically decreased purchase of goods at its own expense and commenced development of commission operations, but the branch failed to lead in this sphere as well. In 1913, cotton yield in the khanate of Khiva (approximately $16 \%$ of all land was occupied with cotton fields) was 1 million pudi (100 thousands of which were used by the local population) ${ }^{66}$. The Moscow business association held the first place for commission sale of cotton (up to 500 carloads). The company, according to the director of the branch, was second to none as it is common

\footnotetext{
62 RGIA. F. 630. Op. 1. D. 474. L. 16 ob., 44, 91, 118.

63 Ibid. D. 475. L. 1-2.

64 Ibid. L. 22-25.

65 Ibid. L. 39-40.

66 Ibid. D. 476. L. 178-179, 180.
} 
practice to issue loans against goods up front, which is of course impracticable for any banking institution ${ }^{67}$. Consecutively, the Novo-Urgench branch only received 67 carloads of cotton for consignment selling ${ }^{68}$.

The World War I destabilized markets and was bound to have a positive influence on the development of commission sale of cotton through the bank. Nevertheless, in December 1914, Vadiaevskoe business association purchased 160 carloads of Khivan cotton in such a manner ${ }^{69}$. However, by May 1916, only 45 carloads of the material were received for consignment sale during the season ${ }^{70}$.

Until August 1914, the branch continued selling alfalfa on Hamburg stock exchange. "During May 1914", the branch's director wrote in his report, "60 carloads of alfalfa were sold in Hamburg and currently there remains of the said alfalfa in the same market: 1911 harvest -25 carloads, $1912-12$ carloads, $1913-59$ carloads, totaling 96 carloads"71. After the beginning of the war, Hamburg stock exchange sales were suspended ${ }^{72}$ which prompted the search for alternative channels for sales. Khivan alfalfa began to be sold to America through Vladivostok. Persian and Russian merchants (Khadji Aga Galiyev and Geyman $)^{73}$ started collaboration on alfalfa export, and gradually alfalfa prices began to increase.

Expenses and profit of the bank's branch. In 1910-1917, the profit of the Novo-Urgench branch of the RACB was of unsteady nature (Table 13).

Table 13. Expenses and profit of the Novo-Urgench branch of the Russo-Asiatic bank, roubles ${ }^{74}$

\begin{tabular}{|c|c|c|c|c|c|}
\hline Year & $\begin{array}{c}\text { Current } \\
\text { expenses }\end{array}$ & Salary expenses & $\begin{array}{c}\text { Interest account } \\
\text { profit }\end{array}$ & Net profit & Net loss \\
\hline 1910 & 56298,16 & 33161,39 & 41721,63 & 57698,67 & 6449,51 \\
\hline 1911 & 67539,01 & 43738,64 & 28260,44 & - & 249772,23 \\
\hline 1912 & 61905,34 & 39053,50 & 125297,63 & 130404,68 & - \\
\hline 1913 & 59715,57 & 38995,50 & 55067,42 & 5342,56 & - \\
\hline 1914 & 56935,26 & 36285,24 & 36283,41 & 36863,06 & - \\
\hline 1915 & 53163,95 & 30663,91 & 32536,93 & 39682,31 & - \\
\hline 1916 & 61849,71 & 28307,63 & 46983,55 & 19539,16 & - \\
\hline 1917 & 128356,04 & 62709,25 & 97171,90 & 26055,40 & - \\
\hline
\end{tabular}

67 Ibid.

68 Ibid.

69 Ibid. L. 200.

70 Ibid. D. 480 . L. 10 ob. -12 ob.

${ }^{71}$ Ibid. D. 476. L. 200.

72 Ibid. L. 191.

73 Ibid. D. 480. L. 28 ob.

74 Ibid. D. 474. L. 11, 11 ob., 12 ob., 29, 29 ob., 31, 47, 47 ob., 48 ob., 75, 75 ob., 76 ob., 94, 94 ob., 95 ob., 121, 121 ob., 122 ob., 151, 151 ob., 152 ob., 170, 171 ob., 172 ob.; D. 475. L.9-11. 
As it becomes evident from the table above, almost half of the branch's expenses were comprised of salary to the employees, the other half included telegraph (almost 2400 roubles per year ${ }^{75}$, refurbishment of premises, fuel and stationery. Pure loss in the amount of almost 6500 roubles in 1910 was due to bankruptcy of S. P. Fomin and his failure to pay loans to the bank. In the correspondence of the branch's director, the reason for bankruptcy is described in sufficient detail and, apparently, so is the standard operating procedure of the bank in a bankruptcy situation. The initial debt of S. P. Fomin was "as per January of the accounting year: 12 thousand roubles - loan issued against 32500 pudi of chigit (cotton seeds. - Authors' note) and 22.756 roubles 13 kopecks - unpaid advances and the price difference between the one agreed upon and paid at his expense, a total of 34756 roubles 13 kopecks... and from our selling of his cotton-ginning factory - 28306 roubles 62 kopecks. The remaining 6449 roubles 51 kopecks, as we do not hold a security or any means of collecting from him, we were forced to write off from our profit for $1910^{\text {"7 }}$. In the annual report for 1910, the losses were explained additionally by permanently high cotton prices on the Khivan market.

In 1911, the branch lost almost 250 thousand roubles on an unsuccessful cotton and alfalfa transaction. In 1913, net profit fell to 5400 roubles, the reason behind such a decrease were protested bills for the amount of 37768 roubles 74 kopecks ${ }^{77}$ as well as bankruptcy of the trading house of the Rizaev brothers. In 1916, profit fell yet again along with a decrease in active operations and an increase in passive operations. Apparently, banking business in Central Asia bore not a few hidden risks.

Inspections of the activities of the Novo-Urgench branch of the Russo-Asiatic bank. Materials from the Russian State Historical Archive allow for detailed scrutiny of two prominent inspections of the Novo-Urgench branch of the RACB. In 1911, inspector A. Slutskii who came from Saint Petersburg for revision branded the division's activity as "righteous chaos"78. The main reason behind such characterization was, according to the inspector, the unsatisfactory work of director V.Y. Komarovskii who, "having wholly dedicated himself to the commercial side of business, paid no regard to the branch's good order"79. The inspector explained the failures with cotton and alfalfa that took place in 1910 and 1911 by profiteering on the part of the division's director ${ }^{80}$.

Slutskii criticized Komarovskii for placing the stake primarily on operations at the bank's own expense ${ }^{81}$, for instance: "in 1910 about 2045 roubles was earned from castor sugar, whereas about 65thousand roubles were spent on it... Purchase of wool, as can be seen from the inspection report, yielded unfavourable result" ${ }^{\prime 2}$. Surely, as A. Slutskii notes, "provided that conditions were extremely favourable, i. e. in case of a significant increase there could have been a good profit". Slutskii argued that in engaging in commodity operations at own expense, the branch provoked strong competition for its own clientele: "firstly, thus the clientele is set against the bank, and secondly, the bank bereaves itself of other operations, such as loans against goods and reception of goods for commission

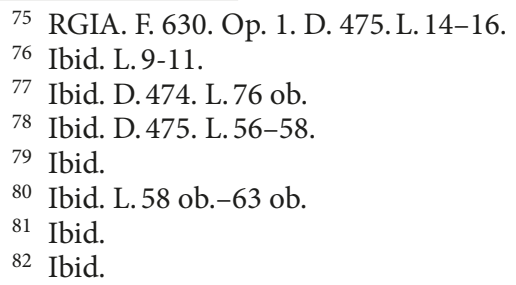


sale" ${ }^{83}$. Slutskii proposed to develop consignment (commission) sale of cotton and alfalfa instead of purchase and sale of goods at own expense and pointed out that "unfortunately, such operation is underdeveloped in the division" 84 .

Following A.Slutskii's revision, V. Komarovskii was transferred to Andizhan branch of the Russo-Asiatic bank. His position was taken over by I. Fruhling ${ }^{85}$.

In 1916, the Novo-Urgench branch of the Russo-Asiatic bank was inspected by bank's inspectors B. Lukod'ianov and R. Tal'ma. Inspectors noted that "the division gave preference to work with clients in the form of loans against goods, rather than bill operations. In point of fact, while over 7 years payments for commodity operations amounted to 21695 thousand roubles, payments for bill operations only reached 8070 thousand roubles" 86 . Bill operations of the branch were reduced to a minimum since Khiva was outside of Russia's direct jurisdiction and such operations could not become widely used. By 1916, bill operations only amounted to 101 thousand roubles (bill negotiation, in particular, 34600 roubles) or barely $8 \%$ of all active assets ${ }^{87}$. The average bill negotiation rate was $10-10,5 \%$, while for on-call it was $9-9,5 \% 88$.

Jointly with the Bakkalov brothers, the bank owned alfalfa-ginning factory in Chimbai, which was written off as a loss in 1910 after the fiasco with alfalfa operations. The experience of joint ownership of the factory, however, should be considered positive. In 1911 losses amounted to 209 roubles, in 1912 profit amountedto 1745 roubles, in 1913 profit amounted to 1162 roubles, in 1914 profit amounted to 443 roubles, in 1915 losses amounted to 432 roubles. With total profit of 2709 roubles for the period of 5 years, the factory, according to the opinion of inspectors from Petrograd B. Lukod'ianov and R. Tal'ma, was already half-requited ${ }^{89}$. The inspectors recommended to continue exploitation of the factory and not to sell it.

On the whole, the conclusions of the 1916 revision were bleak as "active assets of the division amount only to 800 thousand roubles, against which the coefficient of current expenses of estimated 57500 roubles will be $7,2 \%$, in other words, the branch will not by all means be able to cover the expenses with active operations only" ${ }^{\prime \prime}$. The inspectors pointed out the growth in passive operations in the branch and saw future function of the Novo-Urgench branch in supplying cheap money to the bank's administration in Petro$\operatorname{grad}^{91}$.

Clientele of the Novo-Urgench branch of the Russo-Asiatic commercial bank. Local merchants and entrepreneurs can be considered core clients for the whole duration of the period in question: the Bakkalov brothers; Mad'iarov; Salimdzhanov's trading house; trading house of the Manuilov brothers, trading house of the Chernikov brothers, trading house of the Safariants brothers, Duershmidt company, trading house of the Rizaev brothers (who were foreigners from Persia). In 1911, approximately 78 people were considered

\footnotetext{
83 Ibid.

84 Ibid.

85 Ibid. L. 67 ob. -68 ob., 170.

86 Ibid. D. 480 . L. 8 ob. -9 ob.

87 Ibid.

88 Ibid.

89 Ibid. L. 16 ob.

90 Ibid. L. 31 ob. -32 ob.

91 Ibid. L. 45 ob. -47.
} 
the division's major clients ${ }^{92}$. They were Khivan, Russian, Armenian, Persian, German and Tatar merchants; it was not unheard of that the branch carried out trade operations in partnership with them. The Novo-Urgench branch engaged in entrepreneurial activities jointly with depositors, for instance, the branch owned alfalfa-ginning factory in Chimbai jointly with Mad'iarov and the Bakkalov brothers ${ }^{93}$, the factory that attracted close attention of the Petrograd inspectors in 1916.

Trading house of G. Salimdzhanov and sons was an old-established and rich Kazan firm which operated in Khiva and undertook large operations with cotton, other raw materials, wool, manufactured goods, etc. "Until the present, the firm had not turned to us for discount credit, and now, having it among our clients, we hope that there will be no obstacles... in approving the credit for it" ${ }^{\prime \prime 4}$, as it was stated in the report of 1911. Taking into account the volume of business worth millions, the firm was issued a credit of 100 thousand roubles.

Brothers P.A. and K. A. Manuilov were seen by employees of the bank as "pioneers of cotton and oil-pressing businesses and in general of the Russian colonization in Khiva" ${ }^{\prime 2}$. P. A. Manuilov owned factories and real estate in Khanka, Gurlyan and Petroaleksandrovsk, engaged in trading cotton and tea, developed his own oil-pressing and soap manufacture. Documents of the revision bear testimony of the sizeable turnover of the Manuilov brothers. "On-call loans against trading documents are secured by 23 carloads of cotton of different kinds dispatched to Moscow and 2978 pudi of green tea (estimated at 50 roubles) kept in Urgench"96.

The Safaryants brothers owned a cotton-ginning factory in Khodzheili, water-pumping station and huge lots of land which they irrigated by themselves and rented out to the local population. Their main drawer of bill (for 5 thousand roubles), beck of Khodzheili A.H.Murtazakhodzhaev was killed in February 1916 by the revolting Turkmen, other drawers of bills were mostly referred to as "their people" (estate managers, relatives, etc.) ${ }^{97}$.

It is remarkable that Khivan merchants were often high officials of the khan (e. g. A. Bakkalov and M. Muradov) and the division's administration considered it was beneficial to support them from a political point of view. In November 1911, I. I. Fruhling in his letter to the administration of the bank's divisions gave a detailed explanation of the situation. "Increased debt of I. K. D. Mukhammed Muradovand A. B. Akhmethanov was a result of the increase of the loan issued to them: to the former - up to 50 thousand roubles, and to the latter - up to 15 thousand roubles. Mr. Mukhammed Muradov, being a high official of the khan, is a rich and influential man and an interesting client for us since he is related to many other high officials and rich Khivan merchants who we would very much like to see as our clients. As for Mr. Akhmethanov, he is a supplier for Khivan high officials and is indeed an honest and dependable man, hence we do not consider negotiation of his bills a risk"98. The director of the bank's division apparently kept a close watch of the Khivan political situation: "Position of Messrs. Bakkalov at the khan's court strengthened, and to support them, Khan loaned them 40 thousand roubles out of his own

92 RGIA. F. 630. Op. 1. D. 476. L. 29.

93 Ibid. D. 480. L. 2 o6.-5.

${ }^{94}$ Ibid. D. 476. L. 136.

95 Ibid. D. 480. L. 25 ob. -26 ob.

96 Ibid.

97 Ibid. L. 27 ob.

98 Ibid. D. 476. L. 74. 
funds... our concern about them should now become irrelevant"99."By issuing loans to khan's high officials", reported I. I. Fruhling to the administration, "although they do not engage in trade on their own, we aspire to coming closer together with that rather rich khan's entourage, with a view to, on the one hand, potentially taking deposits from them and, on the other, securing our relationship with the Khivan court which is extremely important and necessary for us" 100 .

One of the biggest clients of the bank was A. Mad'iarov, the owner of cotton-ginning factory in Khanki. Here is the characterization that was given to him by his inspector B. Lukod'ianov in 1916: "cotton trader and alfalfa profiteer, A. Mad'iarov, is a typical Khivan old-school merchant, languid and inert. His creditworthiness is unquestionable"101. In March 1916, he on-called 50 thousand roubles against bills, for which he paid 9,5\%, "receiving, at the same time, only 3\% from the current account, i. e. he pays 6,5\% for nothing". It is difficult to judge A. Mad'iarov's commercial aptitude, however, he made a very thought-out political decision. "As any well-off Khivan, fearing khan's confiscation, he prefers to always have a large debt to a Russian credit institution. Nevertheless, since March this year it is us who owe to Avezbai (A. Mad'iarov. - Authors' note) and not vice versa" 102 , wrote the bank's inspectors ironically.

However, it was not always that influential Khivans owed to the Russian lending and finance institution. Brothers Abdurahman and Abduraim Bakkalov and their nephews owned cotton-ginning factories in Novo-Urgench and Tashauz and land lots around the khanate ${ }^{103}$. In 1916, Abdurahman Bakkalov was appointed bek (ruler) for Novo-Urgench and, fearing court schemes, stayed in Khiva almost constantly, and main business affairs were run by his relatives ${ }^{104}$. A. Mad'iarov was A. Bakkalov's partner in purchasing cotton and alfalfa, and it was disposable assets that the latter preferred to keep in the Novo-Urgench branch of the RACB. Inspectors wrote that Bakkalov "is more of our creditor than our debitor; on 13.06.1916, his current account has funds of 34423 roubles and the amount might increase significantly since the Bakkalov brothers are going to receive from the contribution charged to the Turkmen by the Russian military authorities about 350 thousand roubles for recovering of losses they suffered in the course of Turkmen revolt"105.

Large Russian clients of the division were A. I. Putilov and knyaz (prince. - Authors' note) M.M. Andronikov who in 1914 bought "Lauzan"106 estate from the Khivan khan through the Novo-Urgench division of the Russo-Asiatic bank at 550 thousand roubles (installments of 110 thousand roubles were paid to the bank yearly until 1918) ${ }^{107}$. The Khivan ruler, according to the information that the branch's director reported to Saint Peters-

99 Ibid. L. 85-89, 90-91, 92-93, 97-100.

100 Ibid. L. 114-115.

101 Ibid. D. 480. L. 22 ob. -23 ob.

102 Ibid.

103 Ibid. L. 23 ob. -25 ob.

104 Ibid.

105 Ibid.

106 Akifumi S. Who Should Manage the Water of the Amu Daria? Controversy over Irrigation Concessions between Russia and Khiva, 1913-1914 // Explorations in the Social History of Modern Central Asia (19 $19^{\text {th }}-$ Early $20^{\text {th }}$ Century). Leiden; Boston, 2013. P. 111-136.

107 Perepiska Upravleniia otdeleniiami s Novo-Urgenchskim otdeleniem banka ob oformlenii prav na vladenie I raschetakh $s$ Khivinskim pravitel'stvom za priobretennuiu bankom cherez posredstvo Putilova A.I. i Andronikova M. M. dachu 'Lauzan' v Khivinskom khanstve, 1914-1917 gg. // RGIA. F. 630. Op. 1. D. 478. L. 1, 4, 15. 
burg, in December 1914 "promised to deposit 50 thousand roubles for 6 months with $6 \%$ p. a." ${ }^{108}$. The Turkmen upheaval of 1915-1916 thwarted plans of Putilov, Andronikov and Asfhandiyar-khan. The branch's director wrote in August 1915: "Our dacha 'Lauzan' is situated almost in the centre of the district run by khan Mamut's Turkmen, and Turkmen prevail in both its population and population of neighbouring kishlaks"109. It is notable that the bank paid mortmain endowment (waqf) for the 'Lauzan' estate. For instance, as per 1 November 1916, 200 roubles were paid ${ }^{110}$.

Personnel of the Novo-Urgench branch of the Russo-Asiatic commercial bank. The Novo-Urgench branch of the bank desperately needed skillful professionals. In February 1911 in a letter to F. Miliashkevich to Samarkand, the division's director V. Komarovskii described the situation with personnel worriedly: "due to truly dreadful conditions of living, we are going to face a number of similar transfer requests from our employees and thus I humbly request to make it known to us whether there are any employees that are free and would be willing to relocate to our branch"111. Employees of the division constantly complained to their superiors and inspectors about the harsh climate, illnesses in their families and absence of doctors ${ }^{112}$. A. Slutskii during the inspection in 1911 gave uncomplimentary characteristics to some of the branch's employees. In particular, "first attorney, I. G. Levenstein, who was hired by the bank relatively recently, is little familar with banking practices and accounting. Second attorney, I. V. Stoliarov, unfortunately, paid no attention to anything around him. Shmidt, accountant, did not, as a matter of fact, have an opportunity to keep his professional affairs in order due to, firstly, his own lack of experience, secondly, lack of experienced employees, and thirdly, due to the fact that he did not receive timely information pertaining to conditions of transactions with clients and thus could not make accurate records"113. A. F. Forst, a foreign correspondent, was described as a man of "moderate abilities but highly conscientious, responsible and loyal to work". The appraisal of the rest of employees was "good"114.

A. Slutskii paid attention to hard conditions of life in Urgench: "cost of living is frightfully expensive, by way of example: bread costs 10 kopecks per pound, kerosene during my presence there went up to 40 kopecks per pound, saksaul fire wood is up to 50 kopecks per pood, which is the equivalent of 15 roubles per square sazhen 10 vershok of regular firewood or almost 75 roubles per cubic sazhen; most unqualified servants are worth at least 15 roubles per month, almost no clothes or household goods can be bought in Urgench and one has to go to Petroaleksandrovsk, and even there pay a big extra. In case of vacation, anemployeehastospendalmost3 weeks only on the journey to Chardzhui and back, which means more expenses. Due to such conditions, given an opportunity to break away from Urgench, an employee of the branch would flee"115. The inspector suggested that salaries of the division's employees be increased and their weaknesses should be treated

${ }_{108}$ Perepiska Upravleniia otdeleniiami s Novo-Urgenchskim otdeleniem... // RGIA. F. 630. Op.1. D. 478. L. 28 .

109 Ibid. L. 91-95.

110 Ibid. L. 107.

111 Ibid. D. 475. L. 6.

112 Ibid. L. 7-7 об.

113 Ibid. L. 56-58.

114 Ibid. L. 66 ob. $-67 \mathrm{ob}$.

115 Ibid. L. 66-66 ob. 
with more indulgence ${ }^{116}$. I. I. Fruhling, the successor of V. Y. Komarovskii, was forced to ask for a salary increase for his employees: for A. M. Kisliakov - from 1500 to 1800 roubles, for A. V.Podoprigora - from 1500 to 1800 roubles, for V.N. Sitnikov - from 1200 to 1500 roubles, for N. A. Rodzaevskii - from 900 to 1080 roubles ${ }^{117}$.

By 1916, personnel of the Novo-Urgench branch of RACB consisted of the director, 2 attorneys, an accountant, 7 employees, a collector of money, a clerk, a translator and 8 servants. Among the personnel, only I. I. Fruhling, the director, could communicate orally, not in writing - with the local population in the Uzbek language. From the justified perspective of the inspectors, ignorance of the local language and legal intricacies restrained the development in the entire Khivan oasis ${ }^{118}$. However, the inspectors regarded vulgar corruption as the main problem in 1916 as well as in 1911. Most of the newly arrived employees of the bank, namely E. K. Trumpf, Brinkman, H. G. Ivanova-Abel' and her husband V.I. Ivanov were relatives of the wife of the branch's director, Fruhling; a relative of Fruhling himself, an Altergot, was also employed by the branch ${ }^{119}$.

Indignant inspectors pointed out the voluntarist methods of administering the branch: "Fruhling held the keys to trading operations only to himself and even the bank's attorneys saw no applications from clients, dispatches received and sent, orders and even some copybooks - owing to all of the above, even the bank's attorneys themselves are little acquainted with the dealings of our division" 120 . The inspectors noted that "I. Fruhling lays down conditions impossible for the client with the view to consequently offering his own funds at interest and, moreover, a share in the profit, which is done both directly and through Khadzhi Aga (a Persian merchant)"121.

Thereby, by 1916 I. I. Fruhling no longer advocated interests of the bank but rather pursued his own. Personal finances of I. Fruhling, according to the analysis of the inspectors, reached an impressive amount of between 150 and 200 thousand roubles ${ }^{122}$. The branch's director owned a large amount of real estate in Urgench and Khiva as well as several current accounts in the bank ${ }^{123}$. As a result of the revision, I. I. Fruhling was dismissed, and P. P. Moskvin was appointed to take his position.

Conclusion. The Novo-Urgench branch of the Russo-Asiatic bank failed to become a driving force of the economic development of the region. The main reasons behind that were the "adjustment" of the division to the actual economic relationships existing in Turkestan and "autonomies", the Khivan khanate and the Emirate of Bukhara, the special status of the bank's clients at the courts of the local rulers, and issues with personnel.

Concurrently, the Novo-Urgench branch of the Russo-Asiatic bank did not exploit the region's economy but rather helped the local merchantry to increase export and enter both the empire's and international markets. The Novo-Urgench branch of the RACB attempted to control the main exports and even incite development of processing industry in cooperation with local merchants. As can be seen from the reports, in reality the bank's

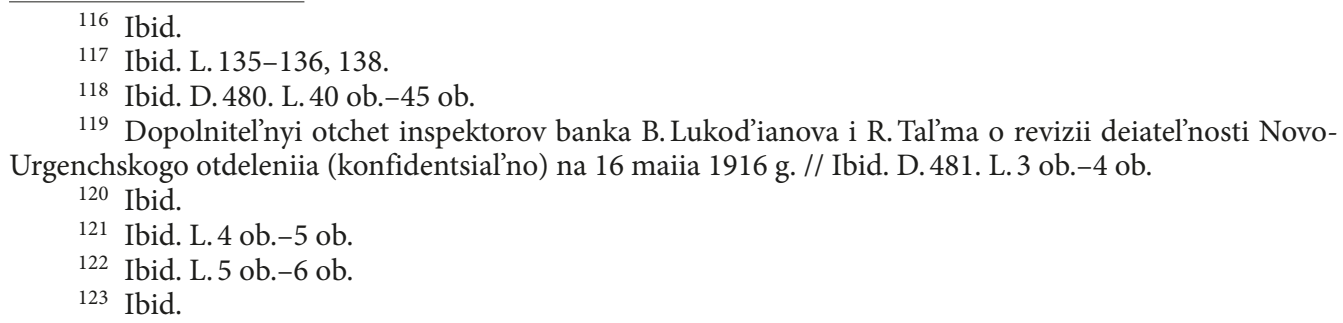

119 Dopolnitel'nyi otchet inspektorov banka B.Lukod'ianova i R. Tal'ma o revizii deiatel'nosti NovoUrgenchskogo otdeleniia (konfidentsial'no) na 16 maiia 1916 g. // Ibid. D. 481 . L. 3 ob.-4 ob.

120 Ibid.

121 Ibid. L. 4 ob. -5 ob.

122 Ibid. L. 5 ob. -6 ob.

123 Ibid. 
branch could only bring $20 \%$ of cotton export under control, and for a short time, 40 $45 \%$ of all alfalfa yield, which was pregnant with financial losses. Mainly the operations of merchants well acquainted with the local market were effectuated through the branch, namely, those of the Bakkalov brothers, Mad'iarov, Manuilov and the Rizaev brothers.

Directors of the division endeavoured to participate in commodity operations on an equal footing with merchants and companies (I.I. Fruhling was fairly successful with machinations at the bank's expense, V.Y.Komarovskii was accused of the same). Owing to external circumstances such as scarce current assets, underdeveloped infrastructure of the region, stock exchange fluctuations and problems with personnel, the Novo-Urgench branch of the Russo-Asiatic bank could not capture and control the Khivan market. On the whole, as evidenced by contemporaries, the banking sphere had no significant effect on the social structure and culture of the khanate ${ }^{124}$. However, there were half-hearted attempts to mend the situation of the local population: in 1911, the division requested the administration for permission to allot funds to build a school for both Russians and locals in Urgench ${ }^{125}$.

The activities of the Novo-Urgench branch of the RACB largely facilitated growth of profiteering with cotton and alfalfa. As in entire Turkestan, the persistent problem of small loans was not yet solved in the region concerned, due to which revenue from cotton-farming was received not by cotton farmers but by usurers and engrosses ${ }^{126}$. By force of objective and subjective circumstances, after the beginning of the World War I, prospects of economic modernization in the Russian Central Asia became nebulous. Contrary to the wide-spread opinion of the Soviet historiography, by the beginning of the 1917 the Russian banking system had not created an economic hierarchy in Khiva.

"Colonial" periphery at a glance from Petersburg-Petrograd seemed an attractive sphere for investment and generation of abnormal profit, but the profiteering nature of Turkestan commodity-based economy and corruptness of employees hampered natural development of the banking sphere.

\section{References}

Akifumi S. Who Should Manage the Water of the Amu Daria? Controversy over Irrigation Concessions between Russia and Khiva, 1913-1914. Explorations in the Social History of Modern Central Asia $\left(19^{\text {th }}-\right.$ Early $20^{\text {th }}$ Century). Leiden; Boston, 2013, pp. 111-136.

Aminov A.M. Economic development of Central Asia (Colonial period). Tashkent, Uzbek SSR State Print, 1959, 298 p. (In Russian)

Gindin I. F. Banks and Economic Policy in Russia $\left(19^{\text {th }}-\right.$ beginning of $20^{\text {th }}$ c.). Collection. Essays of history and typology of Russian banks. Moscow, Nauka Publ., 1997, 622 p. (In Russian)

Kastelskaia Z. D. From the history of Turkestan territory (1865-1917). Moscow, Nauka Publ., 1980, 120 p. (In Russian)

Kitanina T. M. Military-inflationary concerns in Russia 1914-1917. Concern Putilov-Staheev-Batolin. Leningrad, Nauka Publ., 1969, 180 p. (In Russian)

Kitanina T. M. Penetration of large Russian financial capital into the economy of Central Asia at the end of $19^{\text {th }}$ - beginning of $20^{\text {th }}$ centuries. St. Petersburg, Humanitarian book Publ., 2019, 224 p. (In Russian)

124 RGIA. F. 630. Op. 1. D. 476. L. 134-136a

125 Ibid.

${ }^{126}$ Mamaev A. V. Podgotovka reformy upravleniia Turkestanskim kraem v nachale XX v.: Ekonomicheskie aspekty // Nauchnyi dialog. 2019. No. 11. P. 401. 
Khotamov N. B. The role of bank capital in the social and economic development of Central Asia (the beginning of the $90^{\text {s }}$ of the $19^{\text {th }}$ century - 1917). Dushanbe, Donish Publ., 1990, 319 p. (In Russian)

Mamaev A. V. Imperial project of Hungry steppe settlement. Quaestio Rossica, 2019, vol. 7, no. 4, pp. 12591274. (In Russian)

Mamaev A. V. Preparation of the management reform in Turkestan territory in the beginning of the $20^{\text {th }}$ century: economic aspects. Nauchniy Dialog, 2019, no. 11, pp.388-406. (In Russian)

Makhkamova N. R. Social structure of society in Uzbekistan: traditions and transformations (late $19^{\text {th }}$ century to $1920^{s}$ ). Tashkent, Aloqachi Publ., 2009, 323 p. (In Russian)

Pogorelsky I. V. Essays of economic and political history of Khiva Khanate in the late $19^{\text {th }}$ and early $20^{\text {th }}$ centuries. (1873-1917). Leningrad, Leningrad University Press, 1968, 148 p. (In Russian)

Potapova N. Y. History of entrepreneurship in Turkestan (second half of the $19^{\text {th }}-$ beginning of the $20^{\text {th }}$ centuries). Tashkent, UMED Publ., 2011, 152 p. (In Russian)

Sadykov A.S. Russia and Khiva in the late $19^{\text {th }}-$ early $20^{\text {th }}$ century. Tashkent, Fan Publ., 1972, 209 p. (In Russian)

Sadykov A. S. Economic relations of Khiva with Russia in the second half of $19^{\text {th }}-$ beginning of $20^{\text {th }}$ centuries. Tashkent, UzSSR Nauka Publ., 1965, 183 p. (In Russian)

Salomatina S. A. Russian and Soviet banks in countries of Middle and Far East 1890-1920s: transformation of imperial traditions. Economic history: yearbook, 2014, vol. 2013, pp. 568-624. (In Russian)

Sokolov V. V. Colonial Turkestan: economic and industrial condition and development. Moscow, Plekhanov Russian Economic and Industrial Academy of Sciences Press, 2002, 98 p. (In Russian)

Yuldashev A.M. Agricultural relations in Turkestan (end of $19^{\text {th }}-$ beginning of $20^{\text {th }}$ centuries). Tashkent, Uzbekistan Publ., 1970, 256 p. (In Russian)

Yuldashev A. M. Penetration of Russian monopolistic capital in economy of Turkestan (1900-1917). Avtoref. diss. ... kand. econom. nauk. Tashkent, 1961, 20 p. (In Russian)

Vekselman M. I. Russian monopolistic and foreign capital in Central Asia (end of $19^{\text {th }}-$ beginning of $20^{\text {th }} c$.). Tashkent, Fan Publ., 1987, 143 p. (In Russian) 